\title{
Beyond Acclamations and Excuses: \\ Environmental Performance, Voluntary \\ Environmental Disclosure, and the Role of Visibility
}

\author{
Cedric E. Dawkins \\ John W. Fraas
}

The Editor-in-Chief and Springer wish to inform readers of this journal that, in accordance with Springer's Policy on Publishing Integrity, the paper by Cedric Dawkins and John W. Fraas entitled "Beyond Acclamations and Excuses: Environmental Performance, Voluntary Environmental Disclosure and the Role of Visibility" published in Online First under the DOI number 10.1007/s10551-009-0149-2 has been retracted. While the Dawkins/Fraas paper is largely the work of Dawkins and Fraas, it includes some sentences and ideas that previously appeared in an unpublished paper and/or Power Point presentation with the same title only with Cedric Dawkins and Cynthia Clark Williams listed as authors. We regret that the paper was published without any acknowledgement of the earlier collaborative work.

Alex C. Michalos Editor-in-Chief, Brandon University,

Faculty of Arts, Brandon, Manitoba, Canada 